\title{
Some key issues in the design of water wells in unconsolidated and fractured rock aquifers
}

\author{
Una rassegna su alcuni aspetti fondamentali nella progettazione di pozzi per acqua in terreni \\ e rocce
}

Misstear B.

\begin{abstract}
Riassunto: In questo articolo vengono considerati alcuni elementi fondamentali nella fase di progettazione di un pozzo per acqua, fra i quali: la lunghezza della sezione di presa, la lunghezza del rivestimento superiore per pozzi in acquiferi fratturati; il possibile compromesso fra rendimento del pozzo e sicurezza rispetto ad un livello contaminato e infine le valutazioni economiche nella progettazione di un pozzo.

Per pozzi in acquiferi spessi e non consolidati, che siano anche relativamente uniformi, la profondità del pozzo e la lunghezza del filtro possono essere stimate utilizzando una semplice relazione fra portata e curva di abbassamento del livello piezometrico. Questo metodo può permettere di evitare la costruzione di pozzi di profondità sovrabbondante, a patto che in tali situazioni sia utilizzato l'accorgimento alternativo di finestrare l'ultimo terzo inferiore dell'acquifero.

L'efficienza idraulica è un elemento importante da considerare nella fase di progettazione di un pozzo: in questo articolo si vuole sottolineare il fatto che mentre il tema della velocità di entrata nel filtro è stato studiato molto in letteratura, viceversa quello della velocità di risalita ha ricevuto una minore attenzione, sebbene esso sia estremamente influente nella perdita di carico in filtri di diametro piccolo. In caso di progettazione di un pozzo in acquiferi fratturati, può essere necessario trovare un compromesso fra la massimizzazione della produzione del pozzo, utilizzando le zone fratturate superficiali, e la necessaria salvaguardia per garantire gli standard sanitari dell'acqua, installando un rivestimento superiore cementato.
\end{abstract}

Parole chiave: progettazione pozzi; idraulica dei pozzi; trivellazioni economicamente efficaci.

Keywords: well design, well bydraulics, cost-effective boreboles.

Bruce MISSTEAR 奉””

Department of Civil, Structural \&

Environmental Engineering, Trinity College,

Dublin 2, Ireland

bmisster@tcd.ie

Ricevuto: 30 luglio 2012 / Accettato: 3 settembre 2012

Pubblicato online: 30 settembre 2012

(C) Associazione Acque Sotterranee 2012
Alcuni dati recenti provenienti dall'Irlanda, sulla variabilità della conducibilità idraulica rispetto alla profondità, in rocce fratturate di bassa produttività, sono utilizzati per calcolare la riduzione del rendimento del pozzo che potrebbe derivare dell'aumento della lunghezza del rivestimento superiore cementato. Gli aspetti economici della progettazione sono rilevanti specialmente laddove vi sia un numero elevato di pozzi da realizzare, oppure dove la trivellazione sia progettata in zone rurali povere o in paesi in via di sviluppo. In questo articolo vengono riportati i principi base per realizzare una trivellazione economicamente efficace in paesi in via di sviluppo, sottolineando l'opportunità di utilizzare pozzi superficiali e di piccolo diametro, realizzati con macchine perforatrici a basso costo, manuali o comunque aventi una struttura meccanica ridotta al minimo).

Abstract: The key well design issues considered in this paper are the length of the intake section; the bydraulic efficiency of the well; the length of grouted upper casing for wells in fractured rock aquifers and the potential trade-off between well yield and security against pollution; and the economics of well design. For wells in thick, relatively uniform unconsolidated aquifers, the well depth and screen length can be estimated using a simple discharge-drawdown relationship. This approach can belp avoid constructing unnecessarily deep wells if alternative guidance to screen the bottom third of the aquifer was followed in such situations. Hydraulic efficiency is an important consideration in well design: the paper highlights that whereas screen entrance velocity has been a topic of much discussion in the literature, well upflow velocity has received less attention, but can be an important contributor to well losses in small diameter screens. In fractured hard rock aquifers, there may be a compromise required in well design between maximising well yield by exploiting shallow fracture zones whilst also providing adequate sanitary protection to the well by installing an upper grouted casing. Recent data from Ireland on the distribution of hydraulic conductivity with depth in poorly productive fractured rock aquifers are used to calculate the reduction in well yield that would result from increasing the length of the grouted upper well casing. Economic aspects of well design are especially important where there are a large number of wells to be drilled andlor where wells are required in poor rural communities in developing countries. The principles of cost-effective boreholes for developing countries are summarised, noting the opportunities for small-diameter shallow wells constructed with inexpensive manual or lightweight mechanical drilling rigs. 


\section{Introduction}

Wells in some form or other have probably been around since the earliest times of man. The first wells may have been simple excavations around springs and seepages designed to increase the reliability of the supply, or perhaps shallow excavations in dry river beds or along river banks nearby. Records of specific wells can be found as far back as a few millennia BC: a well in Cyprus apparently dates to between 7,000 and 9,500 BC (Fagan, 2011), whilst the oldest well in China, the shallow Hemudu well in the lower Yangtze coastal plain, has been dated to c.3,700 $\mathrm{BC}$ (this is a ${ }^{14} \mathrm{C}$ age for the wooden piles around the well; Zhou et al., 2011). The importance of wells to ancient civilisations is highlighted by the many references to wells contained in the Bible and the Koran.

There are many different types of water well including: hand dug wells, ranging from simple excavations to "improved wells" with concrete or brick lining and sanitary seals which are common in Africa and Asia; infiltration galleries, including the gravity-flow qanats or aflaj found in west Asia, the Arabian peninsula and north Africa; and drilled wells (also referred to as boreholes or tubewells) - these can be vertical (most common), inclined or radial - which are the most common type of wells constructed nowadays and are found across the world. Wells may be used for drinking water supply, irrigation, drainage, industrial purposes, heating/cooling, aquifer cleanup or for monitoring groundwater levels and groundwater quality.

As noted by Misstear et al. (2006) in the preface to their book on water wells and boreholes, the following objectives underpin the design of a water supply well:

- the well should have sufficient yield to meet the demand;

- the water quality should be suitable for the intended use;

- the well should be reliable, requiring as little maintenance as practicable (but some routine maintenance will be required to maintain efficiency);

- the well should be durable;

- the construction and operating costs should not be excessive;

- the well abstraction should not cause unacceptable impacts on neighbouring wells or on the environment.

In order to achieve these objectives, the designer of a modern drilled well must consider many factors: the characteristics of the aquifer and the overlying geological materials; the design yield and hence the pump size; the diameters and lengths of the different sections of the well; the need for a well screen or open hole completion; the choice of lining materials for stability and durability; the groundwater quality; and the costs of drilling and well construction. This paper will focus on some of the most important issues for the designer of water supply wells in unconsolidated and fractured rock aquifers. Issues which will be considered include the length of the intake section; the hydraulic efficiency of the well (especially well upflow head loss); the length of grouted upper well casing in fractured rock aquifers and the potential trade-off between well yield and security against pollution; and the economics of well design, including cost-effective boreholes for rural communities in developing countries.

\section{Wells in unconsolidated aquifers}

In unconsolidated sand and gravel aquifers, the full well must be lined for stability and therefore a well screen is required for the intake section. Nowadays, this screen is often a plastic slotted pipe, although other screens in wide use include steel bridge slot or louvred screens and stainless steel wirewound (continuous slot) screen. Where the aquifer material is both fine grained and has a uniform particle size distribution an artificial gravel pack will be required to fill the annular space between the borehole wall and the screen (gravel pack design is described in several standard texts e.g. Misstear et al. (2006) and Sterrett (2007)). A schematic showing the typical components of a well constructed in an unconsolidated aquifer is shown in Fig. 1.

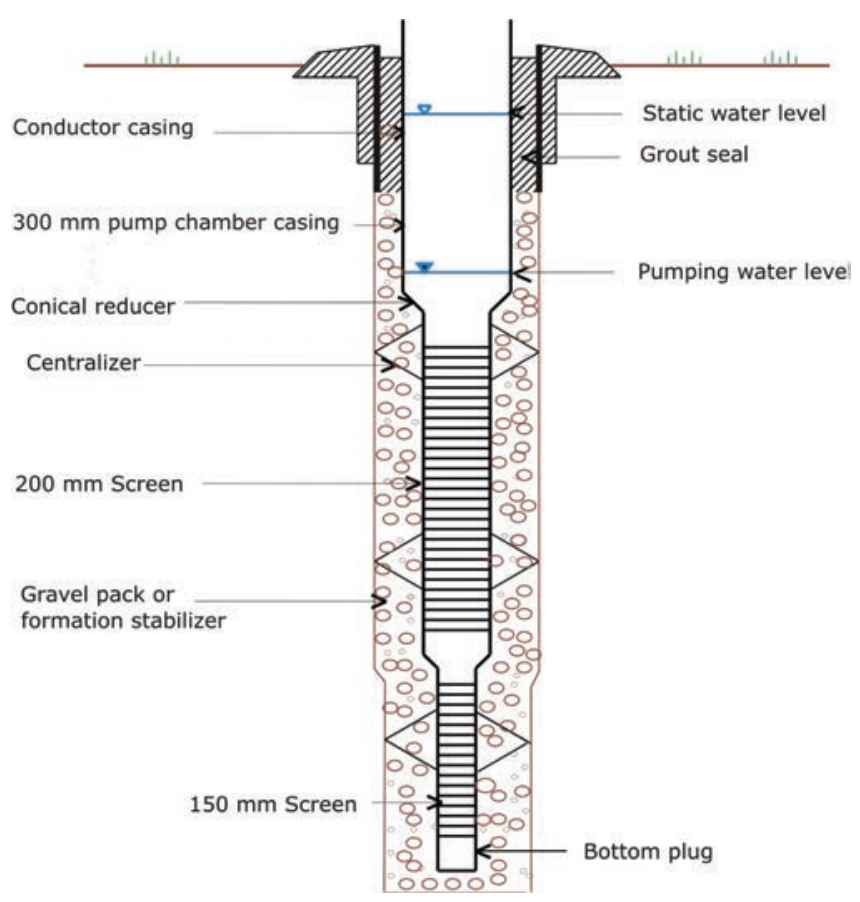

Fig. 1 - Example of well design in an unconsolidated aquifer.

Fig. 1 - Esempio di progetto di un pozzo in un acquifero non consolidato.

In unconfined aquifers it is commonly recommended (Sterrett, 2007) that the lower one third should be screened (this is a pragmatic compromise between screen length and available drawdown). In confined aquifers, the usual recommendation is that $70 \%$ to $90 \%$ of the aquifer should be screened. Where the sedimentary sequence comprises interbeds of gravels, sands, silts and clays, the designer will set the screen sections against the most permeable horizons. 
These general guidelines do not take account of the situation where the aquifer thickness is far in excess of that required to provide the desired well yield. For example, if a $50 \mathrm{~m}$ deep well will provide the design yield, then clearly it is unnecessary to screen the lower third of an unconfined aquifer where this happens to $300 \mathrm{~m}$ thick. In such a situation, a simple calculation can be made to estimate the depth of the well for a particular design yield. Logan (1964) proposed the following simplification of the well-known Thiem equation for steady-state radial flow to a well:

$$
T=K b=\frac{122 Q}{s_{w}}
$$

where $T$ is aquifer transmissivity, $K$ is aquifer hydraulic conductivity, $b$ is aquifer thickness, $Q$ is the well pumping rate and $s_{w}$ is the steady-state drawdown in the well. To estimate the thickness of aquifer to be screened (b) for a particular design discharge $(Q)$ and maximum available drawdown $\left(s_{w}\right)$, the equation can be expressed as:

$$
b=\frac{1.22 Q}{K s_{w}}
$$

This equation assumes Darcian (laminar) flow conditions. To allow for additional drawdown due to non-laminar well losses, the multiplier in the equation is normally increased to 1.5 or 2 (Misstear, 2001), e.g.:

$$
b=\frac{2 Q}{K s_{w}}
$$

For example, if the design yield of the well is $251 \mathrm{~s}^{-1}$ $\left(2,160 \mathrm{~m}^{3} \mathrm{~d}^{-1}\right)$ and the maximum acceptable drawdown is 20 $\mathrm{m}$ (e.g. for maintaining confined aquifer conditions during pumping), then for an aquifer with a mean hydraulic conductivity of say $15 \mathrm{~m} \mathrm{~d}^{-1}$, the screened aquifer thickness will need to be approximately:

$$
b=\frac{2 \times 2160}{15 \times 20} \approx 15 \mathrm{~m}
$$

This is obviously rather a simplistic analysis, and can only be applied where the distribution of $K$ with depth is fairly uniform throughout the aquifer. Also, as discussed below, the well loss component of drawdown increases according to the square of the pumping rate, so the linear relationship in Eq. 3 will become increasingly inaccurate at high pumping rates. Nevertheless, such a calculation can serve as a useful initial guide to the well design, although the proposed screen length and diameter will need to checked in terms of their impact on the hydraulic efficiency of the well design.

\section{Hydraulic efficiency}

The non-laminar head losses that occur when water flows into and up a well are referred to as well losses. Several relationships have been proposed to quantify these well losses. The best known of these is that proposed by Jacob (1946):

$$
s_{w}=B Q+C Q^{2}
$$

where $s_{w}$ is the drawdown in the pumping well, $Q$ is the discharge rate, and $B$ and $C$ are the coefficients of aquifer and well loss, respectively. In this equation the well loss term $C Q^{2}$ indicates that well losses increase according to the square of the discharge rate, whereas the aquifer losses described by the term $B Q$ increase linearly with pumping rate (in accordance with the assumptions underlying the Thiem equation). In reality, some well losses may be laminar, and therefore be included within the $B Q$ term in Eq. 4, whereas the $C Q^{2}$ term may include non-laminar flow in the aquifer zone close to the well, for example in fractures where there are high flow velocities.

Factors that contribute to well losses include the damage zone around the borehole caused by drilling and well construction (skin effects), flow into the well (screen entrance loss) and flow up through the well screen and casing to the pump (upflow loss). For detailed discussions of the components of head loss in a well the reader is referred to Barker and Herbert (1992a; 1992b), Parsons (1994) and Misstear et al. (2006), whilst Barrash et al. (2006) describe some interesting field, laboratory and modelling research on well skin effects at a test site. Only screen entrance loss and well upflow loss are discussed further below.

The screen entrance loss relates to the velocity of water entering a screen $\left(v_{e}\right)$ :

$$
v_{e}=\frac{Q}{\pi D L_{s} A_{e o}}
$$

where $Q$ is the discharge rate, $D$ and $L_{s}$ are the diameter and length of the screen, respectively, and $A_{e 0}$ is the effective open area of the screen (based on the specified open area of the screen, but including an allowance for blockages).

Over the past 50 years there has been a considerable amount written about the issue of a maximum screen entrance velocity to ensure laminar flow in a well. Low entrance velocities are also reported to help reduce long-term corrosion and incrustation of the screen. Several authors have suggested that screen entrance velocity should not exceed $0.03 \mathrm{~m} \mathrm{~s}^{-1}\left(0.1 \mathrm{ft} \mathrm{s}^{-1}\right)$, including Johnson (1966), Driscoll (1986) and Detay (1997). More recently, Sterrett, in the third edition of Groundwater and Wells (2007), retains the recommendation for a maximum screen entrance velocity of $0.03 \mathrm{~m} \mathrm{~s}^{-1}$ and cites research 
by Wendling et al. (1997) which concluded that a maximum screen entrance velocity of 0.03 to $0.06 \mathrm{~m} \mathrm{~s}^{-1}$ is necessary to maintain laminar flow in a well.

Other authors have suggested that significantly higher velocities are acceptable: Williams (1985), who is cited by Roscoe Moss (1990), suggested that maximum screen entrance velocities can be as high as 0.6 to $1.2 \mathrm{~m} \mathrm{~s}^{-1}$ (provided screens have open areas greater than 3 to $5 \%$ ). The previous ANSI/ AWWA standard on water wells (AWWA, 1998) specified an upper limit of $0.46 \mathrm{~m} \mathrm{~s}^{-1}\left(1.5 \mathrm{ft} \mathrm{s}^{-1}\right)$. The document noted that whilst many designers have restricted velocities to 0.03 $\mathrm{m} \mathrm{s}^{-1}$, others have "used and demonstrated successful well designs and installations with velocities exceeding $0.1 \mathrm{ft} / \mathrm{sec}-$ ond $(0.03 \mathrm{~m} / \mathrm{second})$ and, in some cases, up to $2.5 \mathrm{ft} / \mathrm{second}$ (0.76 m/second)". The current ANSI/AWWA A100-06 standard (AWWA, 2006) no longer specifies a maximum screen entrance velocity. The document states that "there is no singular, uniquely defined criterion for permissible velocity through the screen slot openings that is solely suitable for designing a well screen without consideration of the aquifer characteristics and the manner of well construction." The document goes on to say that aspects of flow around the well screen, in the gravel filter and at the interface between the filter and the aquifer, play an important role in well performance. Worked examples in Appendix $\mathrm{L}$ to the standard show a similar design screen length for the contrasting cases of using a screen with $40 \%$ open area and recommended maximum entrance velocity of $0.03 \mathrm{~m} \mathrm{~s}^{-1}$, compared to a screen with $3 \%$ open area and entrance velocity of $0.46 \mathrm{~m} \mathrm{~s}^{-1}$.

The National Ground Water Association is proposing to publish its own water well construction standard. A draft of the proposed ANSI/NGWA-01-07 water well construction standard was issued for public comment in 2011 (NGWA, 2011). This is apparently based on the NGWA's 1998 manual of water well construction practices (NGWA, 1998), with updates. It will be interesting to see what recommendations this document provides on the issue of screen entrance velocity.

Turning now to the issue of well upflow velocity $\left(v_{u}\right)$, this can be calculated from:

$$
v_{u}=\frac{Q}{\pi\left(\frac{D}{2}\right)^{2}}
$$

where $D$ is the diameter of the screen or casing. There has been far less discussion in the literature regarding well upflow velocity than about restricting screen entrance velocity. Where the issue is addressed, it is usually recommended that the upflow velocity should not exceed $1.5 \mathrm{~m} \mathrm{~s}^{-1}$ so as to avoid excessive upflow head losses (Driscoll, 1986; NGWA, 1998; Sterrett, 2007). In contrast, the ANSI/AWWA A10006 standard specifies a slightly lower limit of $1.22 \mathrm{~m} \mathrm{~s}^{-1}$ $\left(4 \mathrm{ft} \mathrm{s}^{-1}\right)$ for the maximum vertical velocity within the well screen (AWWA, 2006).

Two alternative methods are described by Barker and Herbert (1992a; 1992b) and by Bakiewicz et al. (1985) for calculating the upflow head loss in well screens. Based on considerations of friction loss and momentum loss within the well screen, Barker and Herbert (1992b) produced the following relationship:

$$
\Delta h_{s u}=Q^{2}\left(\frac{\alpha L_{s}}{4}+\frac{\beta}{3}\right)
$$

where $\Delta h_{s u}$ is the upflow head loss within the screen, $Q$ is discharge rate, $L_{s}$ is screen length and the parameters $\alpha$ and $\beta$ relate to the screen type and diameter (Parsons, 1994):

$$
\alpha=\frac{32 f}{4 \pi^{2} g D^{5}}
$$

and

$$
\beta=\frac{32 \mu}{\pi^{2} g D^{4}}
$$

where $f$ is a pipe friction factor, $\mu$ is a momentum factor and $g$ is the acceleration due to gravity. In their study of the components of well loss, Barker and Herbert (1992b) concluded that the momentum and frictional losses in the screen represented a large proportion of the non-linear head losses.

Bakiewicz et al. (1985) applied a simpler expression to calculate the upflow head loss in a well screen:

$$
\Delta h_{u}=3.428 q^{2} n^{2} L_{s}^{3} D^{-\frac{16}{3}}
$$

where $\Delta h_{u}$ is the upflow head loss (in $\mathrm{m}$ ), $q$ the flow rate into the screen per unit length of screen $\left(\mathrm{m}^{3} \mathrm{~s}^{-1} \mathrm{~m}^{-1}\right), n$ the Manning roughness coefficient, and $L_{s}$ and $D$ are the length and diameter of the screen $(\mathrm{m})$, respectively. Bakiewicz et al. (1985) mention values for $n$ of 0.013 for slotted pipe and 0.018 for wire-wound screens. In Eq. 10, it can be seen that $\Delta h_{u}$ is inversely proportional to about the fifth power $D$, and hence that upflow head losses will decrease significantly as the screen diameter increases. Fig. 2 a) and b) show some sample calculations of upflow head loss for $12 \mathrm{~m}$ and $24 \mathrm{~m}$ lengths of slotted pipe, respectively, for different pipe diameters and discharge rates. It can be seen that the upflow head losses are significant for the $100 \mathrm{~mm}$ diameter screen at discharge rates in excess of $30 \mathrm{l} \mathrm{s}^{-1}$ (especially for the longer screen) but are relatively small once the diameter is more than 100 $\mathrm{mm}$. Similar graphs can be produced using Eq. 7 instead of Eq. 10 (Misstear et al., 2006). Tab. 1 shows the discharge 


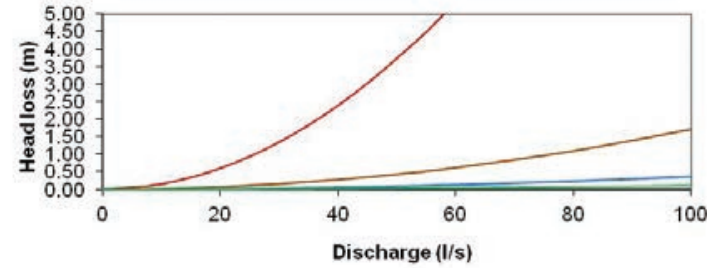

a $-100 \mathrm{~mm}$ $-150 \mathrm{~mm}$ $-200 \mathrm{~mm}$ $-250 \mathrm{~mm}$

Fig. 2a,b-Calculated screen upflow head losses for different discharge rates and screen diameters, assuming $12 \mathrm{~m}$ (Fig $2 a$ ) and $24 \mathrm{~m}$ (Fig $2 b$ ) lengths of slotted casing (calculated using Eq. 10).

Fig. 2a,b -Perdita di carico durante la risalita, per differenti valori di portata e diametri del filtro, calcolata assumendo una lunghezza della finestratura di $12 \mathrm{~m}$ (Fig. 2a) e 24 m (Fig. 2b), rispettivamente, utilizzando Eq.10.

Tab. 1 -Examples of well discharge rates for different screen diameters (from Misstear et al., 2006).

Tab. 1 -Esempi di aliquote di portata nei pozzi al variare del diametro del filtro (da Misstear et al., 2006).

\begin{tabular}{|l|c|c|c|}
\hline $\begin{array}{l}\text { Screen diameter } \\
(\mathrm{mm})\end{array}$ & $\begin{array}{l}\text { Discharge rate }\left(l \mathrm{~s}^{-1}\right) \text { for } \\
\text { maximum upflow velocity } \\
\text { of } 1.5 \mathrm{~m} \mathrm{~s}^{-1}\end{array}$ & $\begin{array}{l}\text { Discharge rate }{ }^{*}\left(l \mathrm{~s}^{-1}\right) \text { for } \\
\text { maximum upflow head } \\
\text { loss of } 0.3 \mathrm{~m}\end{array}$ & $\begin{array}{l}\text { Equivalent upflow } \\
\text { velocity }\left(\mathrm{m} \mathrm{s}^{-1}\right)\end{array}$ \\
\hline 100 & 12 & 11 & 1.4 \\
\hline 150 & 27 & 32 & 1.8 \\
\hline 200 & 47 & 70 & 2.2 \\
\hline 300 & 106 & 205 & 2.9 \\
\hline
\end{tabular}

Note: * this is the discharge rate for a $20 \mathrm{~m}$ length of slotted screen that would give an upflow head loss of $0.3 \mathrm{~m}$, calculated using Eq. 10

rate for different screen diameters that corresponds to a screen upflow head loss of $0.3 \mathrm{~m}$ ( $1 \mathrm{ft})$, which was arbitrarily chosen as an acceptable head loss. A $20 \mathrm{~m}$ length of slotted pipe was assumed in these calculations. The equivalent screen upflow velocity for this discharge rate is also shown in the table, together with the discharge that would be permissible if the maximum upflow velocity is the recommended $1.5 \mathrm{~m} \mathrm{~s}^{-1}$. It can be seen that the $1.5 \mathrm{~m} \mathrm{~s}^{-1}$ limit recommended for upflow velocity appears to be conservative and reasonable.

\section{Wells in fractured rock aquifers}

Whereas the target screen length and depth of a well in a relatively uniform unconsolidated aquifer can be determined to a large extent in advance of drilling, in fractured rock aquifers it is often a matter of exploratory drilling until sufficient water-yielding fractures have been encountered to meet the target yield or, if unsuccessful, moving to a new site and trying again. In certain hard rock formations, such as crystalline basement rocks, the main water bearing zones are often in the weathered saprock above the bedrock and in the upper fractured rock zones within the bedrock, and fractures tend to be less frequent and less open at increasing depths, such that drilling beyond $100 \mathrm{~m}$ depth is seldom worthwhile. In fractured consolidated aquifers such as some limestone and sandstone formations, water-bearing fractures may occur at much greater depths and hence wells may be much deeper than those constructed in crystalline rock aquifers (Misstear et al., 2006).

Fig. 3 shows a typical design for a well in a fractured hard rock aquifer. Here, the overburden is cased off and the main water-producing zone is left unscreened since the rock is stable and does not require support. In deep consolidated sedimentary aquifers, where there are extensive layers of overburden or unstable deposits above the main aquifer, the design may involve installing several permanent well casings in a telescopic fashion i.e. the upper casing is installed to the base of the first unstable horizon, grouted in place and then drilling continues through this casing until the hole requires further stabilisation, when the second casing is "telescoped" through the first casing, sealed, and drilling continues at a reduced diameter, etc.

One of the key aspects of well design in a fractured rock aquifer is proper sealing of the upper casing (or casings). Not only is this required for borehole stability, but it is also necessary so as to prevent surface pollutants migrating down the annular space between the outer wall of the casing and the drilled hole. Recent research on private wells in Ireland has highlighted that these wells can be susceptible to contamination not only in situations where the aquifer has high vulnerability, but even in low vulnerability areas because surface and near-surface pollutants from septic ranks, farmyards etc can enter a well where a proper wellhead or sanitary seal around 


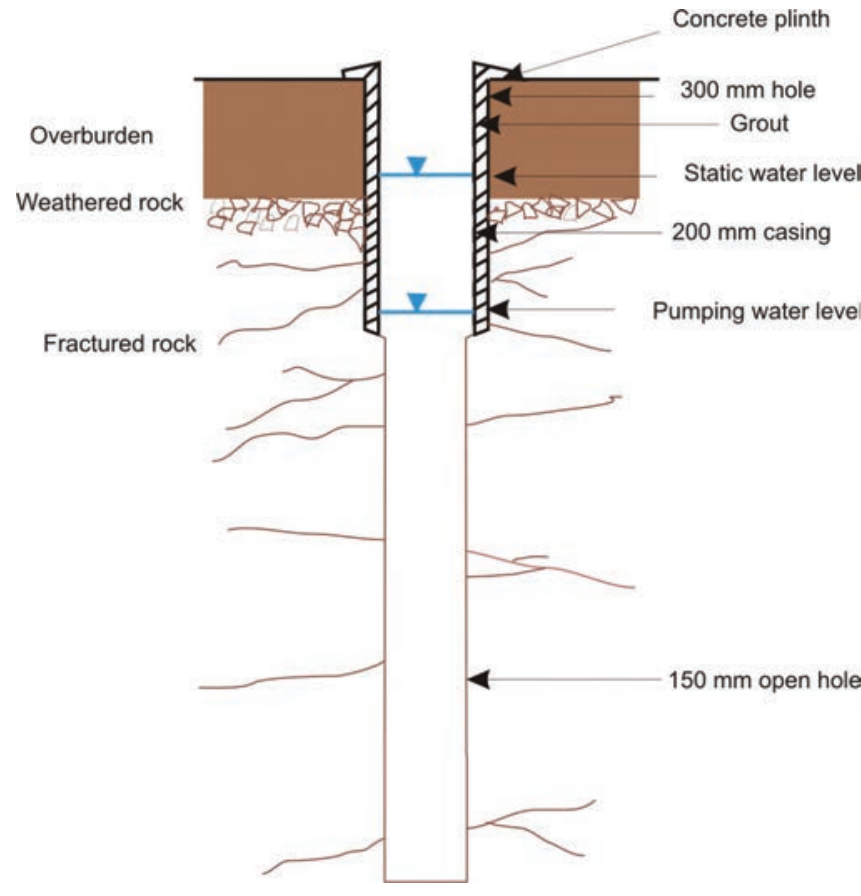

Fig. 3 - Example of well design in a fractured rock aquifer.

Fig. 3 - Esempio di progetto per un pozzo in acquifero a rocce fratturate.

the well casing is absent (Hynds, 2012). In Ireland, it is recommended that the upper permanent casing should extend a minimum of $10 \mathrm{~m}$ into the bedrock to provide the necessary sanitary protection (Institute of Geologists of Ireland, 2007). However, where the upper fractured rock zones are the most productive, there is a trade off between providing increased sanitary protection with a deeper casing and grout seal, but thereby reducing the well yield as the upper most transmissive zones are cased off. This aspect is explored further below, using recent data on aquifer properties from Ireland.

Comte et al. (2012) have investigated the distribution of hydraulic conductivity with depth in three areas in Ireland underlain by contrasting hard rock aquifers, comprising Precambrian and Lower Palaeozoic metamorphic rocks, including schists and gneisses. The basic conceptual model applied in each case involved a fractured and highly-weathered "transition zone" of bedrock just below the overburden, overlying a shallow fractured rock zone which in turn overlies deeper, less fractured bedrock. It was found that the hydraulic conductivity $(K)$ decreased by an order of magnitude between each layer, with (approximate values) $K=0.1 \mathrm{~m} \mathrm{~d}^{-1}$ for the transition zone, $\mathrm{K}=0.01 \mathrm{~m} \mathrm{~d}^{-1}$ for the shallow bedrock and $K=0.001 \mathrm{~m} \mathrm{~d}^{-1}$ for the deeper bedrock (Comte et al., 2012). In this study, the relationship between hydraulic conductivity $(K)$ and depth for each bedrock type could be expressed by an inverse power law:

$$
K=A d^{-B}
$$

where $d$ is depth below top of bedrock and $A$ and $B$ are coefficients relating to the particular rock units. Comte et al. (2012) present values of $\mathrm{A}$ and $\mathrm{B}$ for four different metamorphic rock units in their three study areas in Ireland. The authors note that a similar inverse power law relationship was observed by Ahlbom et al. (1991) in a detailed investigation of a fractured crystalline rock site in Sweden.

As we saw earlier, the relationship between well yield, drawdown and aquifer transmissivity can be expressed simply (for steady-state conditions) by Eq. 1, here expressed as:

$$
Q=\frac{T s_{w}}{1.22}=\frac{K d s_{w}}{1.22}
$$

If we assume a value for available drawdown $\left(s_{w}\right)$, then the potential effect on discharge rate $(Q)$ can be investigated for the situation where hydraulic conductivity $(K)$ declines with depth, and where aquifer thickness $(d)$ reduces as the length of the upper well casing is increased. Fig. 4a) and 4b) illustrate the reduction in well yield as the length of grouted upper casing is increased from $3 \mathrm{~m}$ to $15 \mathrm{~m}$ (below top of the transition zone), for an assumed drawdown of $10 \mathrm{~m}$ and $20 \mathrm{~m}$, respectively, and where the total well depth below top of rock is $60 \mathrm{~m}$. Thus, the potential intake section of the well reduces from $57 \mathrm{~m}$ to $45 \mathrm{~m}$ as the grouted permanent casing is extended from $3 \mathrm{~m}$ to $15 \mathrm{~m}$ into the rock. Whilst the yield versus casing depth relationship varies between the four different rock units, it can be seen that there is a major reduction in predicted well yield in each case. Thus, for the meta-turbidite the yield (for $20 \mathrm{~m}$ drawdown) with $3 \mathrm{~m}$ of casing is nearly $13 \mathrm{~m}^{3} \mathrm{~d}^{-1}$, but reduces to just under $7 \mathrm{~m}^{3} \mathrm{~d}^{-1}$ with $7 \mathrm{~m}$ of casing, and down to less than $4 \mathrm{~m}^{3} \mathrm{~d}^{-1}$ with $15 \mathrm{~m}$ of casing (Fig. 4b). In the example of the pelitic schist, the potential yield (again assuming $20 \mathrm{~m}$ available drawdown) reduces from approximately $5 \mathrm{~m}^{3} \mathrm{~d}^{-1}$ with $3 \mathrm{~m}$ of casing to about 1 $\mathrm{m}^{3} \mathrm{~d}^{-1}$ with $5 \mathrm{~m}$ of casing and less than $0.1 \mathrm{~m}^{3} \mathrm{~d}^{-1}$ with $15 \mathrm{~m}$ of casing.

Apart from the limitations arising from the underlying simplifications in the Logan approximation (and indeed the Thiem equation from which it is derived, including the assumption of an extensive uniform isotropic aquifer which is clearly not the case here), such calculations are, of course, somewhat simplistic and do not, for example, allow for the induced downward leakage from the transition zone and shallow bedrock behind the grouted casing which may contribute to well yield. Nor does the analysis allow for the influence on well yield of variables such as the geometry of the discontinuity network and the presence of fault zones. Also, the calculated yield values are perhaps slightly lower than might be expected for hard rock aquifers. In Scandinavia, for example, the median well yield for the 59,000 crystalline bedrock wells in the Swedish well database is $600 \mathrm{l} \mathrm{h}^{-1}$ $\left(14 \mathrm{~m}^{3} \mathrm{~d}^{-1}\right)$, with a similar value found from the Norwegian 
Casing depth versus discharge (drawdown $=10 \mathrm{~m}$ )

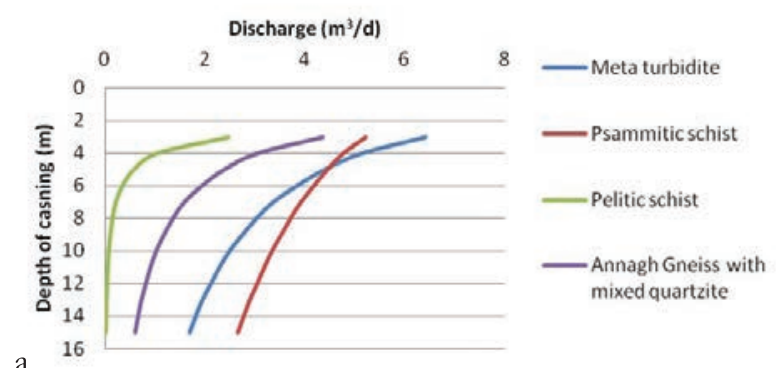

Casing depth versus discharge

(drawdown $=20 \mathrm{~m}$ )

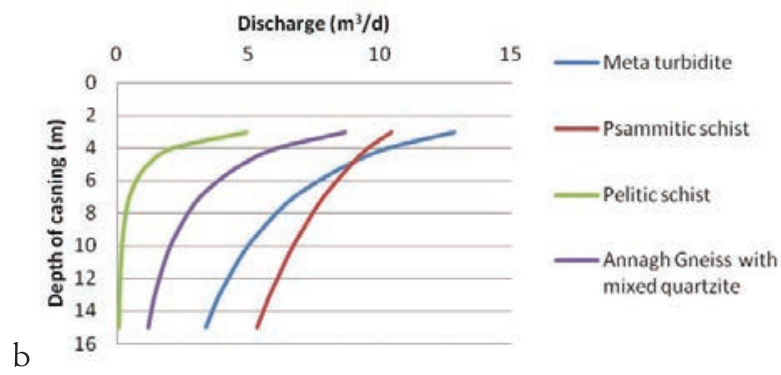

Fig. 4a,b - Calculated well discharge rate versus length of grouted upper well casing in a fractured rock aquifer, where bydraulic conductivity decreases with depth according to an inverse power law. See text for methodology. The hydraulic conductivity data used in the calculations were obtained from Comte et al. (2012). In Fig 4a) the assumed well drawdown $=10 \mathrm{~m}$; in Fig. $4 \mathrm{~b}=20 \mathrm{~m}$.

Fig. 4a,b - Portata del pozzo in funzione della lunghezza del rivestimento cementato superiore, calcolata in un acquifero a rocce fratturate, dove la conducibilità idraulica decresce con la profondità, in modo inversamente proporzionale a una legge di potenza. Si veda il testo per la descrizione del metodo. I dati di conducibilità idraulica sono presi da Comte et al. (2012). Nella Fig. 4a) è assunto un abbassamento piezometrico di 10 m; in Fig. 4b) di 20 m.

database for wells in granites, gneisses and metasediments in Norway (Gustafson, 2002; Banks and Robins, 2002; Misstear et al., 2006). The predicted lower well yields for basement rocks in Ireland using data from the three areas studied by Comte et al. (2012) may be a result of limitations in the simple calculation methodology, or may indicate that the lithologies in these areas are particularly poorly productive, or even possibly suggest that the hydraulic conductivity values are underestimates (although this latter possibility is considered less likely since, as Comte et al. point out, the hydraulic tests on the test boreholes are more likely to give overestimates of $K$ due to the local disturbance and widening of fractures caused by drilling). Nevertheless, the analysis does highlight the potential significant reductions in well yield that may occur when shallow productive zones are cased off.

\section{Well economics}

The cost of an individual water well is often small in comparison to the total cost of a water supply scheme, so the economic considerations in well design may be limited to constructing the well to the appropriate depth and at the required diameter for the required yield and pump, and lining it with materials that will provide the necessary stability and durability. In fractured rock aquifers the well design will be governed mainly by the aquifer geometry. Misstear et al. (2006) provide the following simple guidelines for reducing well construction costs:

- do not drill deeper than necessary;

- do not drill at larger diameter than necessary:

- do not design a gravel pack thicker than needed;

- do not design a screen or casing of greater diameter than necessary;

- do not use expensive materials where cheaper ones will do;

- do not use more screen than is necessary.
In situations where a large number of wells are to be constructed in relatively extensive and uniform aquifers, then the design can be optimised to produce the minimum total capital and operating costs. Whereas the capital cost of a well will increase with borehole depth and length of screen, the operating costs (which mainly relate to pumping costs) will decrease. This can be seen from relationships like that in Eq. 1 where, for a given design yield, the drawdown (and hence pumping cost) will decrease as the length of screen is increased, assuming that hydraulic conductivity is relatively constant with depth. When capital and operating (recurring) costs over the projected lifetime of the well are expressed in

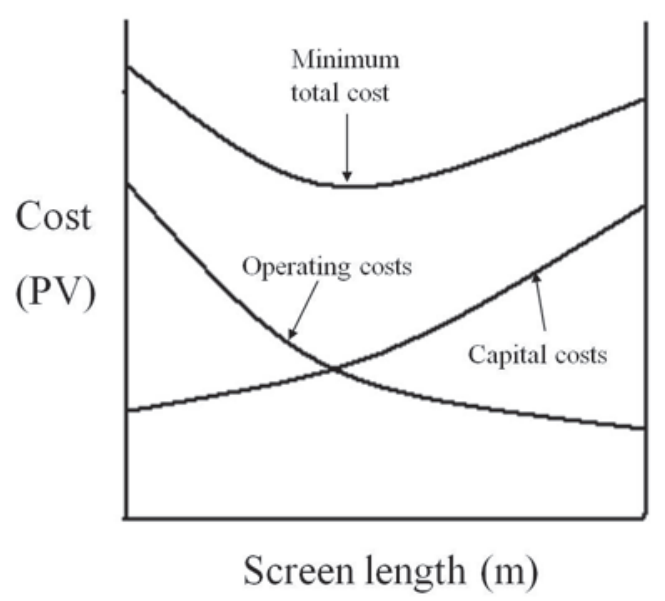

Fig. 5 - Schematic showing the economic optimisation of well design in an extensive uniform aquifer, based on the minimising of total capital and recurring present value $(P V)$ costs.

Fig. 5 - Schema dell'ottimizzazione economica nella progettazione di un pozzo in un acquifero esteso e uniforme, basata sulla minimizzazione del capitale totale riferito al valore attuale (PV) di costi. 
terms of present value, the total costs will show a minimum, as illustrated in Fig. 5. Worked examples of economic optimisation of well design are given in Stoner et al. (1979) - who developed the methodology whilst designing large numbers of irrigation wells in the extensive alluvial aquifers found along the Indus valley in Pakistan - and Misstear et al. (2006).

The costs of well construction are particularly important for poor rural communities, such as those in sub-Saharan Africa, where access to improved water sources is low. Foster (2012) notes that development programmes serving such communities "find it difficult to support capital costs in excess of $\$ 3,000 /$ waterwell”. Danert et al. (2008) present average prices (i.e. amounts paid by Government or projects) for wells in five African countries, which range from $\$ 2,700$ to $\$ 11,700$ per well. The Rural Water Supply Network (RWSN) has been promoting the concept of "cost-effective boreholes" to improve access to sustainable groundwater supplies. The RWSN code of practice for cost-effective boreholes (CEBs) reported in 2010 that 60,000 boreholes a year would need to be constructed in sub-Saharan African alone to meet the Millennium Development Goals (RWSN, 2010). The code identifies nine key principles to achieve CEBs, which can be summarised as:

1. Construction and supervision of boreholes should be undertaken by professional and competent organisations.

2. Borehole siting should include a hydrogeological desk study and field reconnaissance, and take account of the preferences of the local community.

3. The construction method chosen for the borehole should be the most economical, should involve appropriate drilling techniques, and the well depths should be neither over- or under-specified.

4. Appropriate procurement procedures should be followed.

5. The design and construction of the borehole should be cost-effective, based on a minimum specification to achieve a target borehole life of 20 to 50 years.

6. Arrangements need to be in place for adequate supervision, contract management and payment of the drilling contractor.

7. Data from each borehole should be collected and submitted to the relevant Government authority.

8. A hydrogeological database should be established and updated by the relevant Government institution, and the data made freely available to aid future drilling programmes.

9. The functionality of completed boreholes should be monitored.

Principles 3 and 5 are probably of most relevance to this paper. Key aspects of well design that contribute to the capital cost include the well diameter and well depth. Whilst a minimum lining (casing and screen) diameter of $150 \mathrm{~mm}$ ensures accessibility for well maintenance tools, a smaller diameter of $100 \mathrm{~mm}$ can result in significant cost savings and be suf- ficient for CEBs fitted with hand pumps (or in some cases small diameter submersible pumps). In terms of well depth, Doyen (2003; cited in Danert et al., 2008) reported that cost savings of around $25 \%$ could be made for boreholes in Kenya if the boreholes were terminated at the optimum yield depth.

In some countries the available drilling rigs are over-sized and expensive for the drilling task in hand, whereas the use of light-weight rigs could reduce well construction costs. Foster (2012) highlights the importance of reducing well costs by selecting low-cost drilling techniques, and by constructing shallow wells. In some hydrogeological environments in developing countries, especially shallow alluvial aquifers, inexpensive manual drilling techniques may be suitable. Danert et al. (2008) note that a manually-drilled well fitted with a hand pump serving 150 people could be provided at a cost of $\$ 1,000$ (i.e. $\$ 6.67$ per capita) compared to a conventional machine-drilled well serving 300 people, which costs $\$ 9,000$ (\$30 per capita).

\section{Conclusions}

This review of selected key issues in water well design has highlighted:

1. That the depth and screen length for wells to be constructed in relatively uniform and extensive unconsolidated aquifers can be estimated from a simple discharge - drawdown relationship. The application of such an approach can avoid constructing an unnecessarily deep well such as could result, for example, if the designer followed a simple guideline to screen the bottom third of the aquifer where the aquifer is very thick.

2. That although screen entrance velocity has received more attention in the literature, screen upflow velocity and head loss are also important considerations in well design.

3. That the design of wells in fractured rock aquifers may involve a trade-off between using a long section of grouted upper well casing through the overburden into the upper fractured rock layers to provide a good sanitary seal, and using a shorter length of grouted casing which does not block off the shallow water-producing zones but which gives less protection against surface and near surface pollutants entering the well. Data from a recent study of low-productivity fractured hard rock aquifers in Ireland were used to calculate the decline in well yield that would occur as the length of grouted upper well casing was progressively increased.

4. That economic considerations are important in well design where large numbers of wells are involved and/ or where wells are to be constructed at remote rural communities in developing countries. The key principles for cost-effective boreholes in developing countries are outlined, including opportunities for constructing shallow small diameter wells using inexpensive drilling techniques. 
Ackowledgements: The author would like to acknowledge his co-authors of the book Water Wells and Boreholes, David Banks and the late Lewis Clark; together with former colleagues Roy Stoner, Wiktor Bakiewicz and the late Don Milne, for stimulating his interest in well design. Thanks are also due to Ronan O'Brien for assistance in preparing Fig. 4.

\section{References}

Ahlbom K, Andersson J-E, Nordqvist R, Ljunggren C, Tirén S, Voss C (1991) Fjällveden study site. Scope of activities and main results. SKB Technical Report 91-52.

American Water Works Association (1998) AWWA Standard for Water Wells. ANSI / AWWA A100-97, AWWA, Denver.

American Water Works Association (2006) AWWA Standard for Water Wells. ANSI / AWWA A100-06, AWWA, Denver.

Bakiewicz W, Milne DM, Pattle AD (1985) Development of public tubewell designs in Pakistan. Quarterly Journal of Engineering Geology 18: 63-77

Banks D, Robins N (2002) An introduction to groundwater in crystalline bedrock. Norges geologiske unders $\varnothing$ kelse, Trondheim.

Barker JA, Herbert R (1992a) Hydraulic tests on well screens. Applied Hydrogeology 0/92: 7-19.

Barker JA, Herbert R (1992b) A simple theory for estimating well losses: with application to test wells in Bangladesh. Applied Hydrogeology 0/92: 20-31.

Barrash W, Clemo T, Fox JJ, Johnson TC (2006) Field, laboratory, and modelling investigation of the skin effect at wells with slotted casing, Boise Hydrogeophysical Research Site. Journal of Hydrology 326: 1818-198.

Comte J-C, Cassidy R, Nitsche J, Ofterdinger U, Pilatova K, Flynn R (2012) The typology of Irish hard-rock aquifers based on an integrated hydrogeological and geophysical approach. Hydrogeology Journal, published online 20 July 2012, DOI 10.1007/s10040-0120884-9.

Danert K, Carter RC, Adekile D, MacDonald A (2008) Cost-effective boreholes in sub-Saharan Africa. In Proc $33^{\text {rd }}$ WEDC International Conference, "Access to Sanitation and Safe Water: Global Partnerships and Local Actions”, Accra, Ghana, 2008.

Detay M (1997) Water Wells: Implementation, Maintenance and Restoration. J Wiley \& Sons Ltd, Masson, France.

Driscoll FG (1986) Ground Water and Wells, 2nd edn. Johnson Filtration Systems, St. Paul, Minnesota.

Fagan B (2011) Elixir: A human history of water. Bloomsbury, London.

Foster SSD (2012) Hard-rock aquifers in tropical regions: using science to inform development and management policy. Hydrogeology Journal 20: 659-672.

Gustafson G (2002) Strategies for groundwater prospecting in hard rocks: probabilistic approach. Norges Geologiske Unders $\varnothing$ kelse Bulletin 439: 21-25.
Hynds P (2012) Private wells in Ireland: A quantitative assessment of groundwater quality, consumer awareness, contamination susceptibility and human health risk. Unpublished PhD thesis, Trinity College Dublin.

Institute of Geologists of Ireland (2007) Guidelines on water well construction. IGI, Dublin.

Jacob CE (1946) Radial flow in a leaky artesian aquifer. Transactions American Geophysical Union 27: 198-208.

Johnson Division (1966) Ground Water and Wells, $1^{\text {st }}$ edn. Johnson Division, UOP, Saint Paul, USA.

Logan J (1964) Estimating transmissibility from routine production tests of water wells. Ground Water 2: 35-37.

Misstear BDR (2001) The value of simple equilibrium approximations for analysing pumping test data. Hydrogeology Journal 9: 125-126.

Misstear BDR, Banks D, Clark L (2006) Water wells and boreholes. J Wiley \& Sons, Chichester.

National Ground Water Association (1998) Manual of Water Well Construction Practices, 2nd edn. NGWA, Ohio.

National Ground Water Association (2011) ANSI/AWWA-01-07 Water Well Construction Standard (Draft). NGWA, Ohio, USA.

Parsons SB (1994) A re-evaluation of well design procedures. Quarterly Journal of Engineering Geology 27: S31-S40.

Roscoe Moss Company (1990) Handbook of Ground Water Development. John Wiley \& Sons Inc, USA.

Rural Water Supply Network (2010) Code of practice for cost effective boreholes. RWSN, June 2010, British English version.

Sterrett RJ (ed) (2007) Ground Water and Wells, 3rd edn. Johnson Screens, New Brighton, Minnesota.

Stoner RF, Milne DM, Lund PJ (1979) Economic design of wells. Quarterly Journal of Engineering Geology 12: 63-78.

Wendling G, Chapuis RP, Gill DE (1997) Quantifying the effects of well development in unconsolidated material. Ground Water 35(3): 387-393.

Williams DE (1985) Modern techniques in well design. Journal of the American Water Works Association September 1985: 68-74.

ZhouY, Zwahlen F, Wang Y (2011) The ancient Chinese notes on hydrogeology. Hydrogeology Journal 19: 1103-1114. 